\title{
Inhibition of c-Kit signaling by diosmetin isolated from Chrysanthemum morifolium
}

\author{
Seong Jin Lee $\cdot$ Tae-Hoon Jung $\cdot$ Hojeong Kim • \\ Daeyoung Jeong • Gildon Choi · Woo-Kyu Park • \\ Jae Yang Kong $\cdot$ Mu-Hyun Jin · Heeyeong Cho
}

Received: 14 February 2013/Accepted: 15 May 2013/Published online: 26 May 2013

(C) The Author(s) 2013. This article is published with open access at Springerlink.com

\begin{abstract}
The interaction of stem cell factor (SCF) with its cognate receptor c-Kit is closely associated with the survival and maturation of melanocytes. To investigate novel depigmentation agents, we screened 2,000 plant extracts for c-Kit inhibitors to identify active small molecules by using time-resolved fluorescence enzyme assays. For the active extracts identified as inhibitors of c-Kit enzyme, we evaluated the effects of the active extracts and isolated flavonoids on c-Kit phosphorylation in MO7e/ melanocytes. Anti-melanogenic activity was also examined in melanocytes and melanoderm model. The flavonoids such as diosmetin, apigenin, acacetin and luteolin isolated from Chrysanthemum morifolium were found to be active in inhibiting c-Kit both at enzyme and cellular levels. In addition, these flavonoids attenuated SCF-induced proliferation of human primary melanocytes without toxicity and suppressed ultraviolet (UV) B irradiation-mediated melanin synthesis significantly. Among the active flavonoids, diosmetin was found to inhibit SCF-induced melanogenesis in a human melanoderm model. These results strongly suggest that $C$. morifolium extract and diosmetin have
\end{abstract}

\footnotetext{
S. J. Lee - T.-H. Jung - D. Jeong · G. Choi - W.-K. Park ·

H. Cho $(\bowtie)$

Pharmacology Research Group, Drug Discovery Division, Korea

Research Institute of Chemical Technology, Gajeongno 141,

Yuseong-gu, Daejeon 305-343, Korea

e-mail: hycho@krict.re.kr

H. Kim · M.-H. Jin

Cosmetic Research Center, LG Household \& Healthcare Ltd., 84 Jang-dong, Yuseong-gu, Daejeon 305-343, Korea

J. Y. Kong

College of Pharmacy, Keimyung University,

1095 Dalgubeol-daero, Daegu 704-701, Korea
}

potential to suppress SCF-/UVB-induced melanogenesis, and could be developed as anti-pigmentation agents.

Keywords c-Kit · Flavonoid · Diosmetin ·

Depigmentation $\cdot$ Chrysanthemum morifolium

$\begin{array}{ll}\text { Abbreviations } \\ \text { SCF } & \text { Stem cell factor } \\ \text { UVB } & \text { Ultraviolet B } \\ \text { BL } & \text { Butanol layer of } C \text {. morifolium extract } \\ \text { DOPA } & \text { L-dihydroxyphenyl-alanine }\end{array}$

\section{Introduction}

The association of stem-cell factor (SCF, steel factor) with its receptor c-Kit (CD-117, Kit) mediates signaling that is critical for melanocyte survival, proliferation, differentiation, and migration (Alexeev and Yoon 2006; Halaban 2000; Wehrle-Haller 2003). The binding of SCF to c-Kit induces autophosphorylation on tyrosines in the $\mathrm{COOH}$ terminus of c-Kit, which activates its kinase (Mol et al. 2004; Roskoski 2005). In connection with cell survival, c-Kit activates multiple downstream signaling pathways, including the Ras/Raf/mitogen-activated protein kinase kinase (MAPKK)/mitogen-activated protein kinase (MAPK) pathway and the phosphatidylinositol 3-kinase (PI3K)/protein kinase B (AKT) pathway (Hemesath et al. 1998; Roskoski 2005). Furthermore, the over-expression or mutation of c-Kit has been observed in many human solid tumors (Hirota et al. 1998). Consequently, c-Kit has been extensively studied as a target in anticancer drug development and as a key protein in melanogenesis (Attoub et al. 2002; Kato et al. 2004). 
Studies with transgenic mice that carried SCF under the keratin promoter showed that SCF promoted the migration of melanocytes out of niches. When these mice were treated with a c-Kit antibody (ACK2), their progeny had white (unpigmented) skin and hair (Nishimura et al. 2002). Interestingly, a few reports have shown that patients treated with imatinib (Gleevec) exhibited onset of hypopigmentation (Brazzelli et al. 2007; Tsao et al. 2003).

Melanogenesis is generally up-regulated by ultraviolet (UV) light. UV light exerts its effects directly on melanocytes or keratinocyte-derived factors (Hirobe 2005). SCF/c-Kit signaling also plays a key role in the early phase of melanocyte activation during UVBinduced pigmentation (Hachiya et al. 2001; Hosaka et al. 2004; Tobiishi et al. 2005). Exposure to UV or treatment with SCF increases the number of melanocytes in the dermis, mainly through the c-Kit-mediated signaling cascade (Kawaguchi et al. 2001). Once activated, c-Kit phosphorylates the microphthalmia-associated transcription factor (MITF) via mitogen-activated protein kinase (MAPK); subsequently, the phosphorylated MITF promotes melanocyte maturation (Hemesath et al. 1998; Tachibana 2000). Therefore, blocking c-Kit signaling can radically prevent pigment formation through inhibition of both melanoblast differentiation and melanogenesis, rather than simply by inhibiting tyrosinase transcription.

Several small molecules have been developed or documented as whitening agents, including hydroquinone, kojic acid, arbutin, ascorbic acid, and retinoic acid. Currently, most whitening agents used in both the cosmetic and medical markets inhibit the activity of tyrosinase (Briganti et al. 2003).

Recently, we isolated emodin as a suppressor of c-Kit signaling by screening a synthetic library based on naturally occurring compounds (Lee et al. 2009). Here, we screened 2,000 plant extracts for c-Kit inhibitory activity and isolated anti-melanogenic flavonoids. Flavonoids are natural polyphenolic compounds that are reported to have anti-oxidative and kinase-inhibitory effects. For example, the flavonoids, quercetin, luteolin, and genistein, were shown to inhibit the kinase activities of epithelial growth factor receptor (EGFR), protein kinase C (PKC), and focal adhesion kinase (FAK) (Agullo et al. 1997; Huang et al. 1999; Kandaswami et al. 2005). Several recent reports have also described the diverse effects that flavonoids have on melanogenesis in human skin and other cell lines (An et al. 2008; Nagata et al. 2004; Ohguchi et al. 2006), however, the mechanism of action for c-Kit is unclear. In this study, we investigated whether flavonoids from Chrysanthemum morifolium might suppress melanogenesis through specific effects on c-Kit.

\section{Materials and methods}

Materials

All the chemicals, except those specifically mentioned, were purchased from either CalBiochem (CA, USA) or Sigma Co. Ltd (MO, USA). The intracellular domain of the c-Kit protein was obtained from ProQinase (Germany). Kinase substrates were purchased from PerkinElmer (MA, USA) and anti-c-Kit antibody (pY719 and total-c-Kit) were obtained from Cell Signaling (MA, USA). The plateletderived growth factor receptor (PDGFR) tyrosine kinase inhibitor III, 4-(6,7-dimethoxy-4-quinazolinyl)- $N$-(4-phenoxy phenyl)-1-piperazinecarboxamide, (521232, CalBiochem, CA) was used as a reference c-Kit inhibitor.

In vitro time-resolved fluorescence (TRF) kinase assay

The inhibition of c-Kit ( $N$-terminal GST-tagged recombinant human Kit, amino acid T544-V976 expressed by baculovirus system in $S f 9$ insect cells, ProQinase) was determined in a TRF assay. Briefly, c-Kit $(20 \mathrm{ng} / \mathrm{well})$ was incubated for $30 \mathrm{~min}$ at room temperature (RT) with $1.5 \mu \mathrm{M}$ of peptide substrate (Biotin-VEEEAPEDLYKDFLTLEH, synthesized in Peptron, Daejeon, Korea), $10 \mu \mathrm{M}$ ATP, and compounds to be tested for inhibition in a buffer containing $50 \mathrm{mM}$ Tris ( $\mathrm{pH} 7.5$ ), $5 \mathrm{mM} \mathrm{MgCl} 2,5 \mathrm{mM} \mathrm{MnCl} 2,2 \mathrm{mM}$ DTT, and $0.01 \%$ Tween-20. The reaction mixture was transferred into a streptavidin-coated DELFIA 96-well plate (PerkinElmer) and incubated for $1 \mathrm{~h}$. After washing 3 times with PBS/T $(\mathrm{pH}$ 7.0), the plates were further incubated with antiphosphotyrosine (p-Y-100) antibody for $1 \mathrm{~h}$ and with Europium-labeled secondary anti-mouse antibody for $30 \mathrm{~min}$; then the plate was rinsed again three times with PBS/T. Finally, Europium Enhancement Solution (PerkinElmer) was applied, and the TRF signal was measured in a Victor2 microplate reader (PerkinElmer). All experiments were performed in duplicate. $\mathrm{IC}_{50}$ values were obtained from a nonlinear regression analysis with GraphPad Prism version 5.0 for Windows (GraphPad Software, San Diego, CA).

\section{AlphaBead kinase assay}

Kinase activity was also determined using AlphaScreen ${ }^{\mathrm{TM}}$ phosphotyrosine (P-Tyr-100) assay kit (PerkinElmer, CT, USA). ALPHA (Amplified Luminescent Proximity Homogeneous Assay) is a bead-based immunoassay monitoring the energy transfer from streptavidin-coated donor bead to anti-phosphotyrosine antibody conjugated acceptor bead. The kinase assay was performed according to the 
protocol provided by the manufacturer. Briefly, kinase $(5 \mu \mathrm{L}$, 2.5-10 ng) was incubated with $5 \mu \mathrm{L}$ of kinase reaction buffer (50 mM Tris- $\mathrm{HCl}(\mathrm{pH} 7.5), 5 \mathrm{mM} \mathrm{MgCl} 2,5 \mathrm{mM} \mathrm{MnCl}$, 2 mMDTT and $0.01 \%$ Tween-20) containing a compound to be tested in a 384-well plate for $15 \mathrm{~min}$ at RT. Then, $5 \mu \mathrm{L}$ of the reaction buffer containing biotinylated poly[Glu:Tyr](4:1) substrate (final conc. $5 \mathrm{nM}$ ) and ATP (final conc. $10 \mu \mathrm{M}$ ) were added and allowed to stand at RT for $1 \mathrm{~h}$. The reaction was quenched by the addition of the capture buffer containing EDTA $100 \mathrm{mM}, \mathrm{NaCl} 250 \mathrm{mM}, 62.5 \mathrm{mM}$ HEPES, donorstreptavidin and acceptor P-Tyr-100 beads (final conc. $20 \mu \mathrm{M}$ ). After $1 \mathrm{~h}$ incubation at RT, AlphaScreen signal was detected in Fusion ${ }^{\mathrm{TM}}$ microplate analyzer (PerkinElmer). All the assays were performed in white 384-well plates (Greiner Bio-One, Germany) in a final volume of $25 \mu \mathrm{L}$.

\section{Cell culture}

All mammalian cells were grown in an appropriate culture media containing antibiotics $(100 \mathrm{U} / \mathrm{mL}$ penicillin and $100 \mu \mathrm{g} / \mathrm{mL}$ streptomycin) in a humidified incubator under $5 \% \mathrm{CO}_{2}$ at $37^{\circ} \mathrm{C}$. MO7e cells (M-07 human megakaryocytic leukemia cell line) were generously provided by Dr. YoungHee Lee (Chung-buk National University, Chungju, Korea). Primary melanocytes were obtained from circumcised tissue from a newborn baby. NCCmelan5 cells (mouse melanocyte cell line) were kindly donated by Dr. Mizoguchi and Yoko Kawa (St. Marianna University, Japan (Ooka et al. 2001)). MO7e cells were routinely propagated in Iscove's Modified Dulbecco's Medium (GIBCO, CA, USA), supplemented with heat-inactivated $10 \% \mathrm{FBS}$ and $1 \mathrm{ng} / \mathrm{mL}$ granulocyte macrophage colony stimulating factor (GM-CSF). NCCmelan5 cells were grown in Eagle's minimum essential medium (EMEM; GIBCO) supplemented with $15 \%$ FBS, $50 \mathrm{ng} / \mathrm{mL}$ murine stem cell factor (mSCF; CHEMICON), and $100 \mathrm{nM}$ endothelin 3 (EDN3). SK-mel2 cells were cultured in RPMI media supplemented with $10 \%$ heat-inactivated FBS. Human primary melanocytes were maintained in MCDB153 media (Sigma, MO, USA) supplemented with $1 \%$ FBS, $10 \mathrm{ng} / \mathrm{mL}$ phorbol 12-myristate 13-acetate (TPA), $5 \mu \mathrm{g} / \mathrm{mL}$ insulin, $0.5 \mu \mathrm{g} / \mathrm{mL}$ hydrocortisone, $1 \mathrm{ng} / \mathrm{mL}$ basic fibroblast growth factor (bFGF), $10 \mathrm{nM}$ alpha-melanocyte stimulating hormone $(\alpha-\mathrm{MSH})$, and $1 \mu \mathrm{g} / \mathrm{mL}$ transferrin.

\section{Western blot analysis}

For Western blot analysis, cells were seeded at $70 \%$ confluence in 6-cm dishes and deprived of cytokines in media supplemented with $1 \%$ FBS for about $16 \mathrm{~h}$. Subsequently, the test compounds were added for $45 \mathrm{~min}$. Then the cells were stimulated with $50 \mathrm{ng} / \mathrm{mL} \mathrm{SCF}$ for $10 \mathrm{~min}$. To prepare the whole cell lysates, cells were washed twice with PBS and lysed. Then, cell lysates were electrophoretically separated on a $6 \%$ SDS-polyacrylamide gel. Proteins were transferred onto Immobilon P-PVDF membranes (polyvinylidene fluoride, Millipore, MA, USA) overnight at $4{ }^{\circ} \mathrm{C}$. Membranes were blocked with TBS containing $5 \%$ skim milk and $0.1 \%$ Tween $20, \mathrm{pH} 7.4$ for $1 \mathrm{~h}$ and then incubated sequentially with primary and secondary antibodies diluted in blocking buffer. Protein bands were detected with an enhanced chemiluminescence detection system (Cell Signaling, MA, USA) on a LAS-3000 (Fuji, Japan).

\section{Isolation of diosmetin from C. morifolium}

The air-dried flowers of $C$. morifolium were treated with $100 \%$ methanol using the reflux method. The resulting methanol extract of $C$. morifolium was successively fractionated with $n$-hexane, chloroform, and $n$-butanol. Then, the $n$-butanol fraction of $C$. morifolium was separated by silica gel column chromatography with chloroform-methanol $(20: 1 \sim 2: 1)$ to yield ten fractions. Effective fractions were purified by preparative HPLC (MERCK/SEPTECH) using a reverse phase column (CombiHT SB-18, $5 \mu \mathrm{m}$, $21.2 \mathrm{~mm} \times 150 \mathrm{~mm})$ and acetonitrile $(35 \sim 50 \%)$ to yield four fractions $\mathrm{Y} 1, \mathrm{Y} 2, \mathrm{Y} 3$ and $\mathrm{Y}$ 4, which were identified as acacetin, diosmetin, apigenin, and luteolin, respectively, by comparing NMR spectroscopic data with the previously reported ones (Cai et al. 2000; Christophoridou et al. 2005; Kraus et al. 2008; Seijas et al. 2005)

MTT and $\left[{ }^{3} \mathrm{H}\right]$-thymidine incorporation assays

Cytotoxic effects were evaluated with a MTT (3-[4,5dimethylthiazol-2-yl]-2,5-diphenyltetrazolium bromide; thiazolyl blue) viability assay. The MTT assay is a standard colorimetric assay that measures the activity of enzymes that reduce MTT to insoluble purple formazan crystals. Cells were seeded on 96-well plates at a density of $1 \times 10^{4}$ cells per well and treated with the test compounds at various concentrations for $48 \mathrm{~h}$. Ten microliters of $5 \mathrm{mg} / \mathrm{mL}$ MTT solution was added and cells were incubated for $1 \mathrm{~h}$. The medium was aspirated and $100 \mu \mathrm{L}$ of DMSO was added to each well. After $10 \mathrm{~min}$ of incubation, the absorbance was measured at $570 \mathrm{~nm}$.

Changes in cell proliferation were measured with a $\left[{ }^{3} \mathrm{H}\right]-$ thymidine incorporation assay. Cells were seeded at a density of $5 \times 10^{3}$ cells per well on a 96-well plate. The next day, cells were pre-incubated with the test compounds for $1 \mathrm{~h}$ and then stimulated with SCF $(100 \mathrm{ng} / \mathrm{mL})$ for another $\left.6 \mathrm{~h} .{ }^{3} \mathrm{H}\right]$-Thymidine was added at $0.05 \mu \mathrm{Ci}$ per well and cells were further incubated for $48 \mathrm{~h}$. After the cells were rinsed three times with PBS, a scintillation cocktail was added. Incorporated radioactive thymidine was counted on a MicroBeta scintillation counter (PerkinElmer). 


\section{$\left[{ }^{14} \mathrm{C}\right]$-tyrosine incorporation assay}

Melanin content was assessed with radioactive tyrosine. Melanocytes were seeded on 96-well plates at a density of $1 \times 10^{4}$ cells per well. The cells were allowed to stabilize for $24 \mathrm{~h}$, then they were treated with the test compounds for $1 \mathrm{~h}$, and then stimulated with $100 \mathrm{ng} / \mathrm{mL}$ of SCF or $30 \mathrm{~mJ}$ of UVB $(312 \mathrm{~nm})$ with a BIO-SUN irradiator (Vilber Lourmat, France). $\left[{ }^{14} \mathrm{C}\right]$-tyrosine (Amersham Pharmacia Biotech, England) was added at $0.03 \mu \mathrm{Ci}$ per well and cells were incubated for $48 \mathrm{~h}$. After the cells were washed with PBS three times, the radioisotope taken up by the cells was measured in a MicroBeta (PerkinElmer).

\section{DOPA assay}

Pigments synthesized from L-dihydroxyphenyl-alanine (DOPA) were visualized after DOPA supplementation. Melanocytes were serum-starved for $18 \mathrm{~h}$; then, they were either irradiated with $30 \mathrm{~mJ}$ UVB or treated with SCF (100 ng/mL). Cells were incubated with the test compound or the reference compound for $48 \mathrm{~h}$. After the medium was exchanged with serum-free media, cells were treated with $10 \mathrm{mM}$ DOPA (Sigma Chemicals Co.) for $3 \mathrm{~h}$ at $37^{\circ} \mathrm{C}$. After removing the cell media, crystal mount was dropped on top of the cells and subsequently, cells were dried at $50{ }^{\circ} \mathrm{C}$. Photos were taken in an inverted microscope $(40 \times$ or $100 \times)$. The melanin content (total intensity \pm S.D.) in each photo was analyzed with the image program MetaMorph $^{\circledR}$ (Molecular Devices).
MelanoDerm assay

MelanoDerm $^{\text {TM }}$ (MEL-300-A-LLMM, MatTek, USA) is a human three-dimensional tissue model. This tissue model was used to test the effect of diosmetin against SCF. Melanoderm tissue was transferred into a 6-well plate with a cell culture insert atop a culture stand (MEL-STND). The culture medium contained pre-warmed EPI-100-LLMM $(0.9 \mathrm{~mL})$ and was placed below the cell insert to feed the basolateral side of the cells; $100 \mu$ of PBS was placed on top of the cell inserts. EPI-100-LLMM (MatTak) is a commercial DMEM-based medium that contains $\alpha-\mathrm{MSH}$, bFGF, EGFR, insulin, hydrocortisone, and other proprietary stimulators of epidermal differentiation. Cells were incubated in SCF $(200 \mathrm{ng} / \mathrm{mL})$ for three days; then, compounds were applied for 2 more weeks. Fresh medium $(5 \mathrm{~mL})$ was applied to the basolateral side of the tissue every other day. Melanoderms were fixed with $10 \%$ formalin and photos were taken from the top-view with a phase contrast microscope at $100 \times$ magnification.

\section{Results}

Inhibition of c-Kit phosphorylation by $C$. morifolium

In search of c-Kit inhibitors, we evaluated 2,000 plant extracts with an enzymatic c-Kit assay. Twenty-one plant extracts showed $>70 \%$ inhibition of c-Kit phosphorylation in vitro (data not shown). These 21 plant extracts were
Fig. 1 Plant extracts were tested for inhibition of c-Kit phosphorylation in MO7e cells. a Twenty-one hit samples selected from a c-Kit enzyme assay were tested on MO7e cells. Cells were pre-treated with the indicated natural extracts for $45 \mathrm{~min}$, and then treated with $50 \mathrm{ng} / \mathrm{mL} \mathrm{SCF}$ for $10 \mathrm{~min}$. In the immunoblot analysis, phosphorylated c-Kit was detected with anti-phospho (Y719) antibody. b The selected C. morifolium extract was further tested at the indicated concentrations. $R$ is the reference inhibitor (521232, $10 \mu \mathrm{M})$
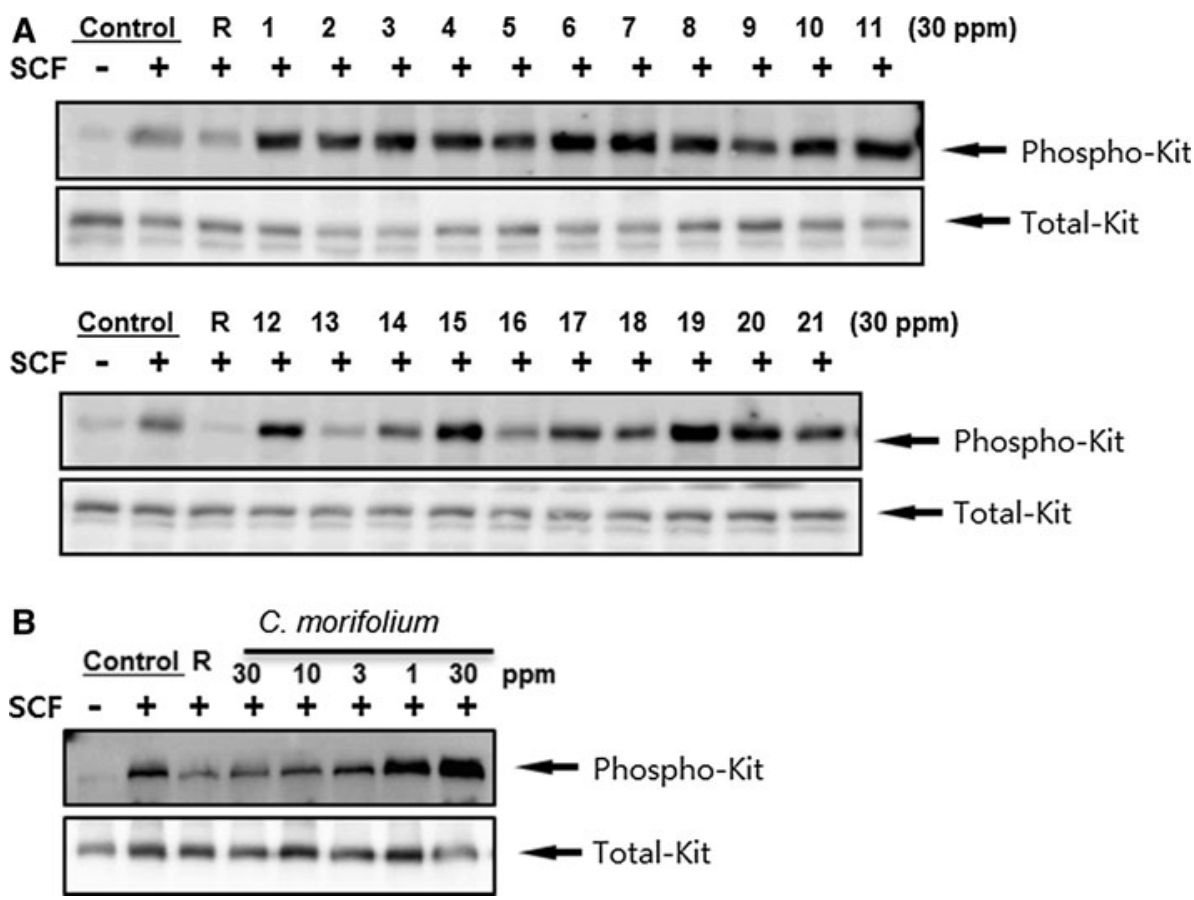
tested to determine whether they could block SCF-induced cellular c-Kit activation in megakaryocytic leukemia (MO7e) cells. Cells were pretreated with the indicated natural extracts and then treated with SCF. Phosphorylated c-Kit (pY719) was assessed in cells treated with or without SCF (Fig. 1). Downstream from c-Kit phosphorylation,
A

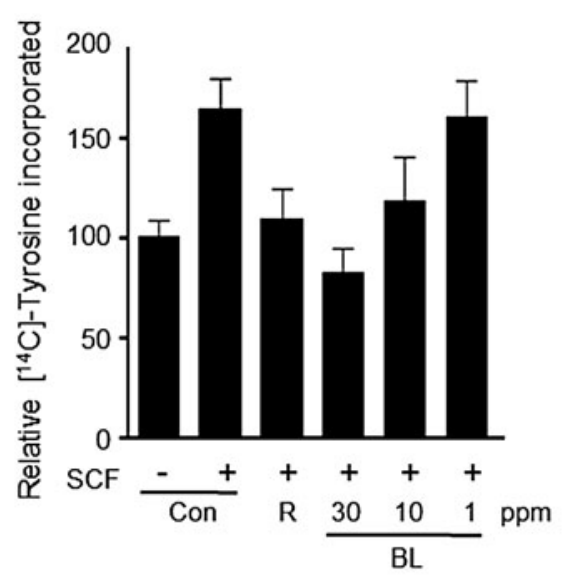

C
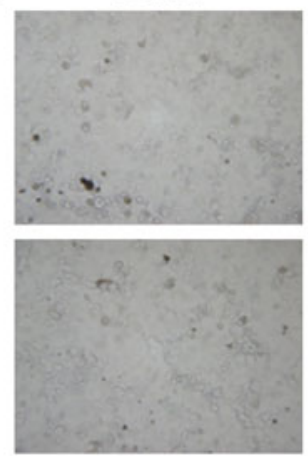

$\mathrm{SCF}+\mathrm{BL} 30 \mathrm{ppm}$

D
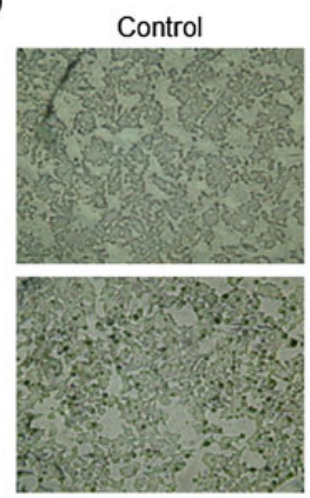

UVB + BL 30 ppm
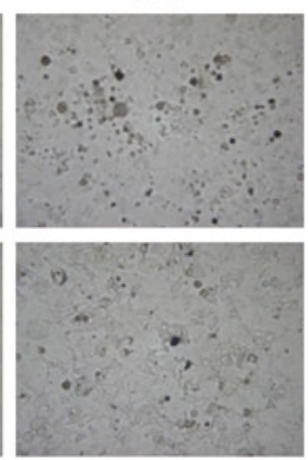

$\mathrm{SCF}+\mathrm{BL} 10 \mathrm{ppm}$

$30 \mathrm{~mJ}$ UVB
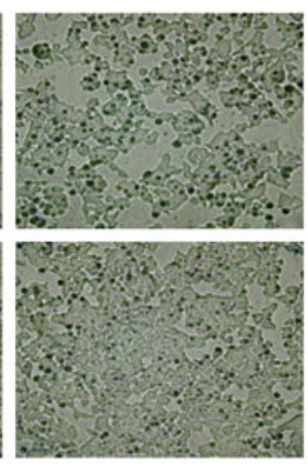

UVB + BL $10 \mathrm{ppm}$
B

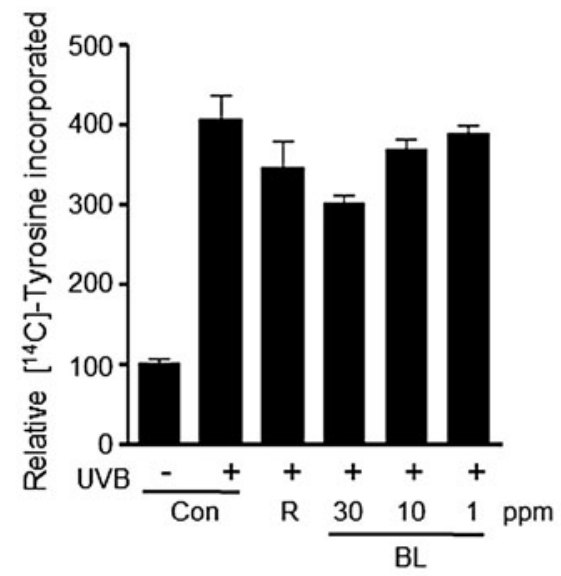

$\mathrm{SCF}+\mathrm{R}$
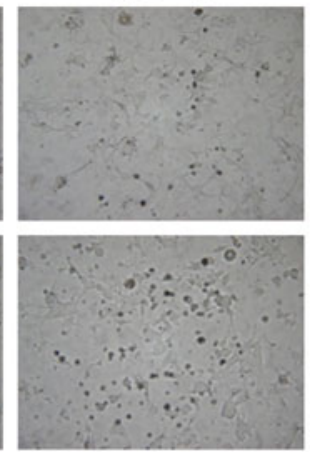

$\mathrm{SCF}+\mathrm{BL} 3 \mathrm{ppm}$

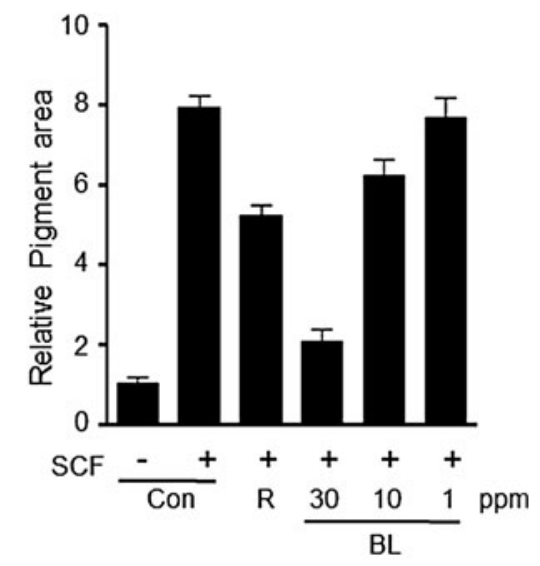

Fig. 2 Anti-pigmentation effect of the BL from the C. morifolium extract. a $\left[{ }^{14} \mathrm{C}\right]$-tyrosine incorporation was determined in NCCmelan5 cells after $48 \mathrm{~h}$ treatments with SCF $(100 \mathrm{ng} / \mathrm{mL})$. b $\left[{ }^{14} \mathrm{C}\right]$-tyrosine incorporation was determined in NCCmelan 5 cells $48 \mathrm{~h}$ after UVBirradiation $(30 \mathrm{~mJ})$. c Representative data from DOPA assay after UVB-irradiation of NCCmelan5 cells. After exposure to SCF, cells were pretreated with the indicated concentrations of the $\mathrm{BL}$ and incubated for $48 \mathrm{~h}$. The DOPA assay was performed, and the photos
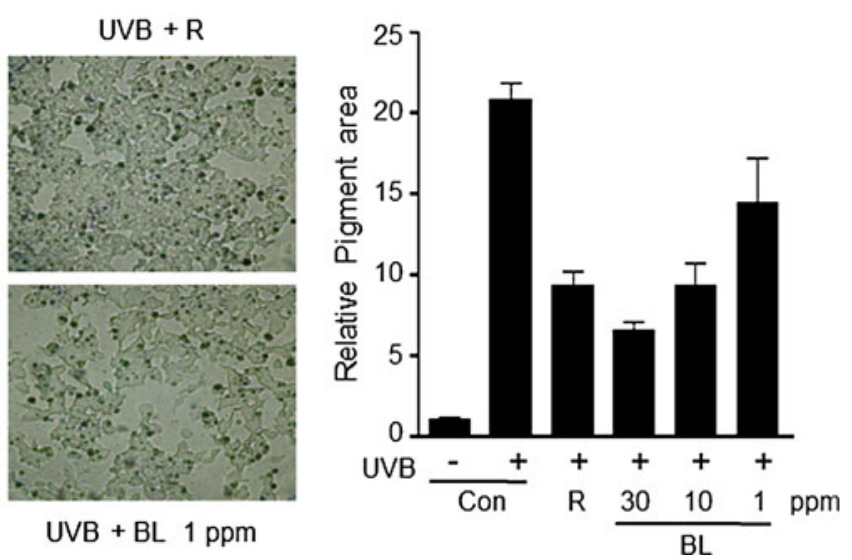

$(\times 100)$ were taken with an inverted microscope. d DOPA assay in NCCmelan 5 cells $18 \mathrm{~h}$ after stimulation with $30 \mathrm{~mJ}$ of UVB. Cells were incubated with the BL fraction for $48 \mathrm{~h}$. After the medium was exchanged with serum-free media, the DOPA assay was performed and photos were taken at $\times 40$ magnification. The $R$ is the reference inhibitor $(521232,3 \mu \mathrm{M})$. The pigment areas of melanocytes were quantitated using program MetaMorph from three independent experiments (c \& d right panels) 
extracellular signal-regulated kinase (ERK) responded consistently (data not shown). At the initial test concentration (30 ppm), only two extracts (serial numbers 13 and 16; C. morifolium and Panax japonicus) showed significant inhibition of c-Kit phosphorylation. The C. morifolium extract was selected for further purification because it showed the most potent dose-dependent inhibition of cellbased c-Kit phosphorylation in MO7e cells. Among the two fractions separated from the $C$. morifolium extract, the butanol layer (BL) exhibited higher inhibitory activity for c-Kit phosphorylation than the water layer. Therefore, the BL was submitted to chromatography with a silica gel column and then fractions were separated with preparative HPLC in reverse phase.

Chrysanthemum morifolium extract suppressed SCF-/UVB-induced pigmentation

Pigments like eumelanin and pheomelanin are synthesized from tyrosine and DOPA (Sugumaran 2002). In our study, melanin synthesis was monitored by both tyrosine and DOPA incorporation assays. With exposure to $30 \mathrm{ppm}$ of the BL fraction, SCF-induced melanin synthesis was completely blocked, and total synthesis was reduced by half (Fig. 2a, c). Furthermore, we tested whether the extract of $C$. morifolium could inhibit UVB-induced pigmentation since $\mathrm{SCF} / \mathrm{c}-\mathrm{Kit}$ signaling is activated in the early phase of melanogenesis during UVB irradiation. The increased pigment formation induced by UVB irradiation (30 mJ, a single dose) was also attenuated by treatment with the BL fraction at a concentration of $30 \mathrm{ppm}$ in mouse melanocytes and human melanoma SK-mel2 cells (Fig. 2b, d).

Identification of flavonoids from C. morifolium that inhibit c-Kit

All four of the compounds (Y1 Y4) isolated from the BL fraction by HPLC showed effective inhibition of c-Kit phosphorylation in mouse melanocytes at $0.3 \sim 1.0 \mathrm{ppm}$ (Fig. 3a). The separated compounds from the concentrated four fractions were identified as acacetin, diosmetin, apigenin, and luteolin by NMR and mass spectrometry analysis. Enzyme inhibitory activities of the isolated compounds were confirmed with AlphaBead kinase assay in vitro. In enzymatic assay, Luteolin demonstrated the strongest inhibitory
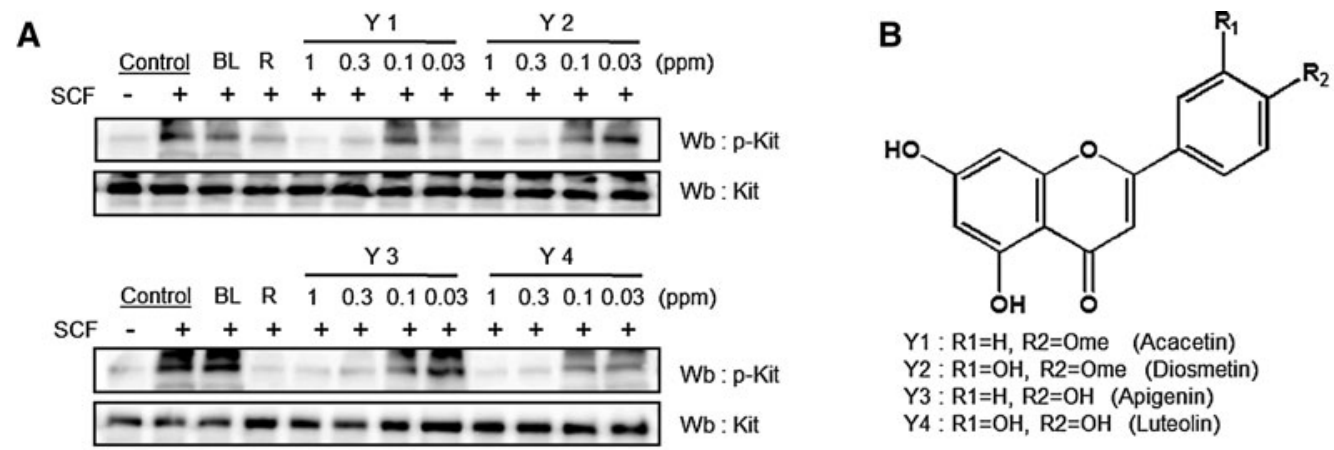

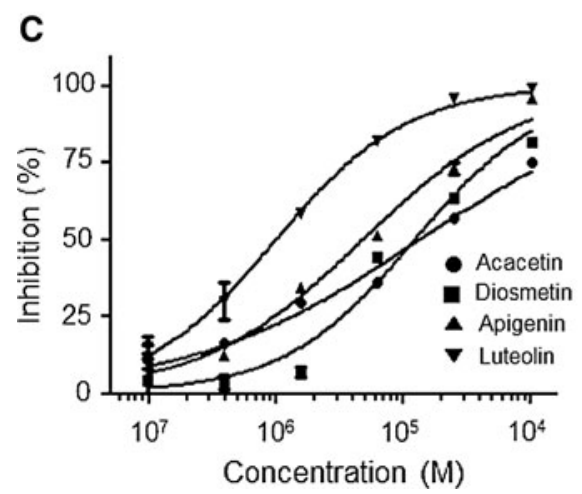

Fig. 3 Four compounds isolated from C. morifolium were tested for inhibition of c-Kit phosphorylation in mouse melanocytes. a Cells were pre-treated for $45 \mathrm{~min}$ with $\mathrm{BL}(0.3 \mathrm{ppm})$ and the four final fractions $\mathrm{Y} 1 \sim \mathrm{Y} 4$ separated from BL. Then, $50 \mathrm{ng} / \mathrm{mL}$ of SCF was added for $10 \mathrm{~min}$. Phosphorylated c-Kit was detected with antiphospho (Y719) antibodies. b The structures of four active
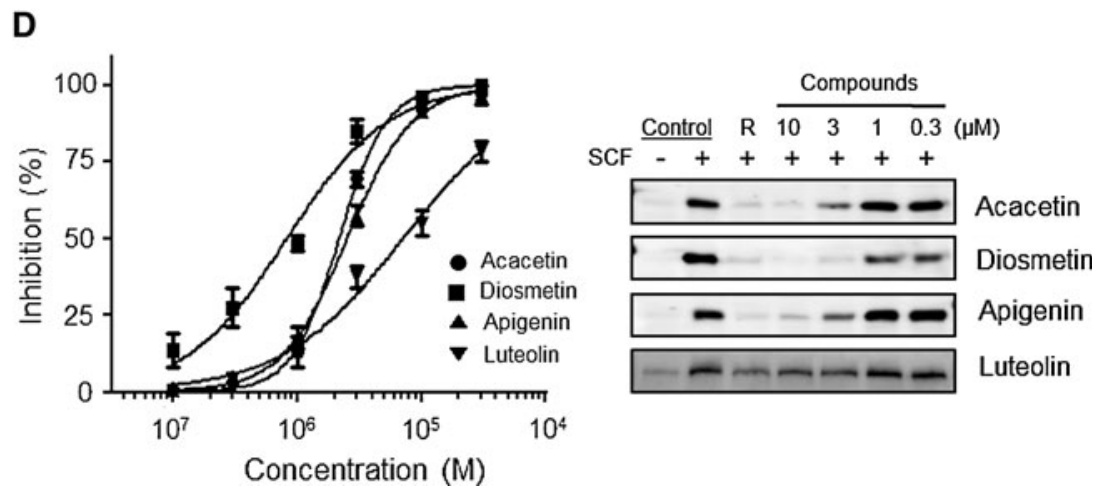

compounds from fractions $\mathrm{Y} 1 \sim \mathrm{Y} 4$ purified from the $\mathrm{BL}$ of the C. morifolium extract. c c-Kit enzyme inhibition by acacetin, diosmetin, apigenin, and luteolin (AlphaBead assay). d Cell based c-Kit inhibition by the four purified compounds in NCCmelan 5 cells. $R$ is compound 521232 at $3 \mu \mathrm{M}$ 
A

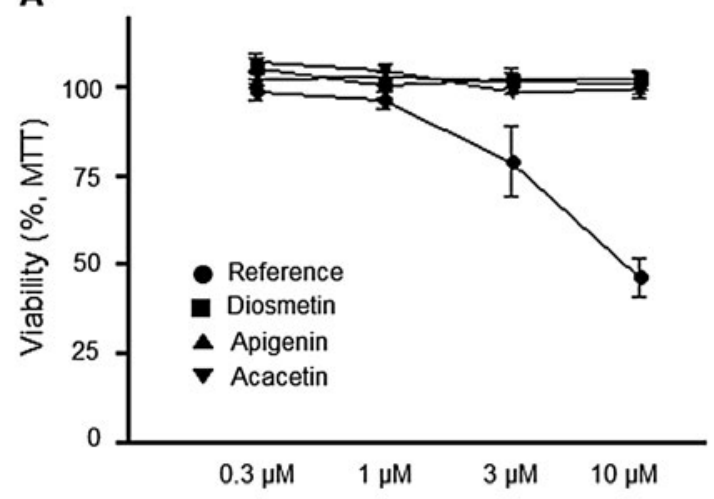

B

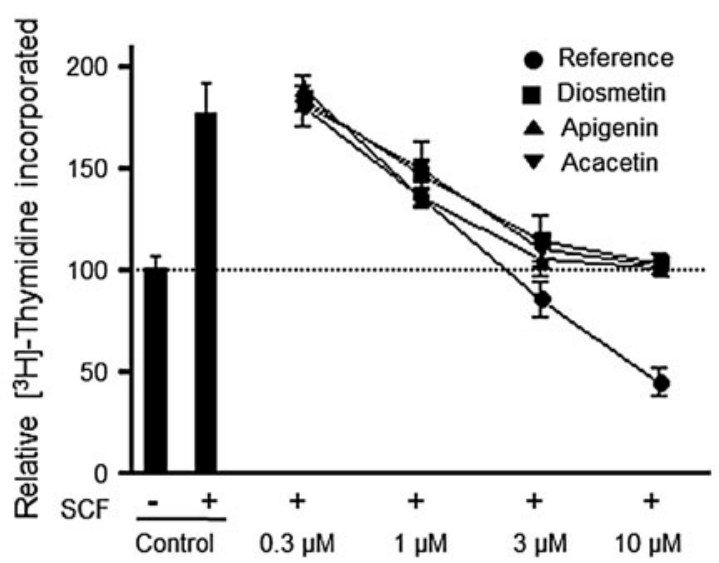

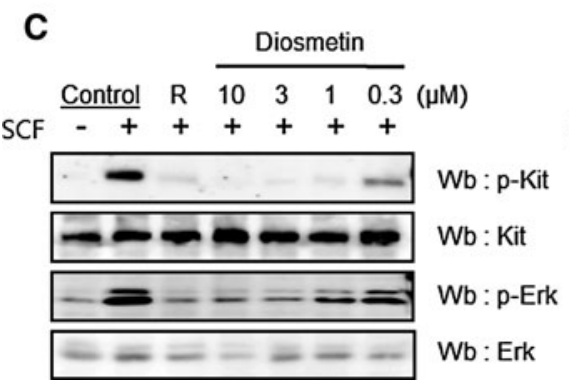

Fig. 4 The effect of flavonoids on SCF/c-Kit signaling in human melanocytes. a The influence of SCF and flavonoids on viability of human melanocytes was determined in $48 \mathrm{~h}$. The MTT assay was performed as described in the "Materials and Methods". b Proliferation of human melanocytes for $48 \mathrm{~h}$ was measured by $\left[{ }^{3} \mathrm{H}\right]-$ thymidine incorporation assay. $\mathbf{c}$ Representative immunoblot analysis of c-Kit and ERK after treatment with inhibitors. Compounds were

potency and the other three showed moderate inhibition: $\mathrm{IC}_{50}=1.0,4.7,12.1$, and $13.3 \mu \mathrm{M}$ for luteolin, apigenin, diosmetin, and acacetin, respectively (Fig. 3c). However, the cellular inhibitory potencies of the four flavonoids were determined to be diosmetin $(0.8 \mu \mathrm{M})>$ acacetin, apigenin $(2.5 \mu \mathrm{M})>$ luteolin $(9.2 \mu \mathrm{M})$ in cultured NCCmelan5 cells (Fig. 3d). The first three active flavonoids based on cellular c-Kit inhibition were used in following studies with human melanocytes.

SCF-induced proliferation of human melanocytes was suppressed by diosmetin, apigenin, and acacetin

Cytotoxicity and anti-proliferative effects were determined with MTT and $\left[{ }^{3} \mathrm{H}\right]$-thymidine incorporation assays. The three active flavonoids up to $10 \mu \mathrm{M}$ did not affect cell viability within $48 \mathrm{~h}$, but a reference compound, 521232, showed cytotoxicity at $>3 \mu \mathrm{M}$ (Fig. $4 \mathrm{a}$ ). When cells were treated with $100 \mathrm{ng} / \mathrm{mL}$ SCF, proliferation was accelerated about 2-fold compared to untreated cells. However, the SCF-stimulated proliferation was nearly blocked by preincubations with $3 \mu \mathrm{M}$ of diosmetin, apigenin, and acacetin pretreated at the indicated concentrations for $45 \mathrm{~min}$ and $50 \mathrm{ng} / \mathrm{mL}$ of SCF was applied for $10 \mathrm{~min}$; then the Western blot was performed. For detection of c-kit phosphorylation, we used anti-phospho-c-Kit (p-Y-719), total-c-Kit, phospho-ERK (T202/Y204), or total-ERK antibodies. $\mathrm{R}$ is the compound 521232 at $3 \mu \mathrm{M}$; values are expressed as the mean values $\pm \mathrm{SD}$ of three independent experiments

(Fig. 4b). Also, c-Kit inhibition experiment of the three flavonoids in human melanocytes gave similar results comparing to mouse melanocytes. Immunoblot analysis of c-Kit phosphorylation showed that diosmetin was the most potent c-Kit inhibitory flavonoid among these three compounds; at $1 \mu \mathrm{M}$ concentration diosmetin almost removed the phosphorylated c-Kit band (Fig. 4c). Diosmetin, apigenin, and acacetin also significantly reduced ERK phosphorylation induced by SCF stimulation.

Inhibition of melanin synthesis by diosmetin in human melanocytes

Melanin synthesis of human melanocytes was induced either by SCF treatment or UV irradiation. SCF-stimulated melanin synthesis in human primary melanocytes was remarkably reduced by the addition of diosmetin, apigenin, or acacetin (Fig. 5a). In particular, diosmetin $\geq 3 \mu \mathrm{M}$ ) completely blocked SCF-induced $\left[{ }^{14} \mathrm{C}\right]$-tyrosine incorporation; thus, tyrosine was only incorporated at normal (SCF non-treated) levels. Also, melanin synthesis induced by UVB irradiation was partially blocked by these active 

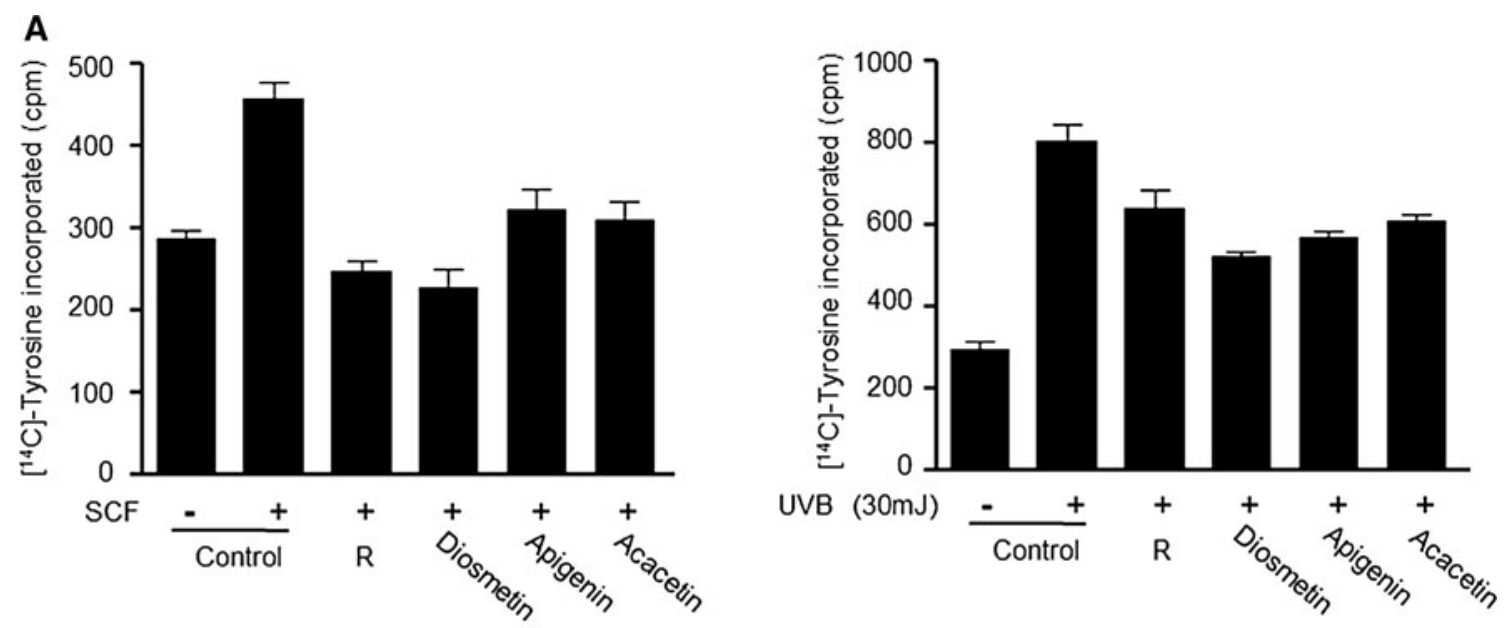

B
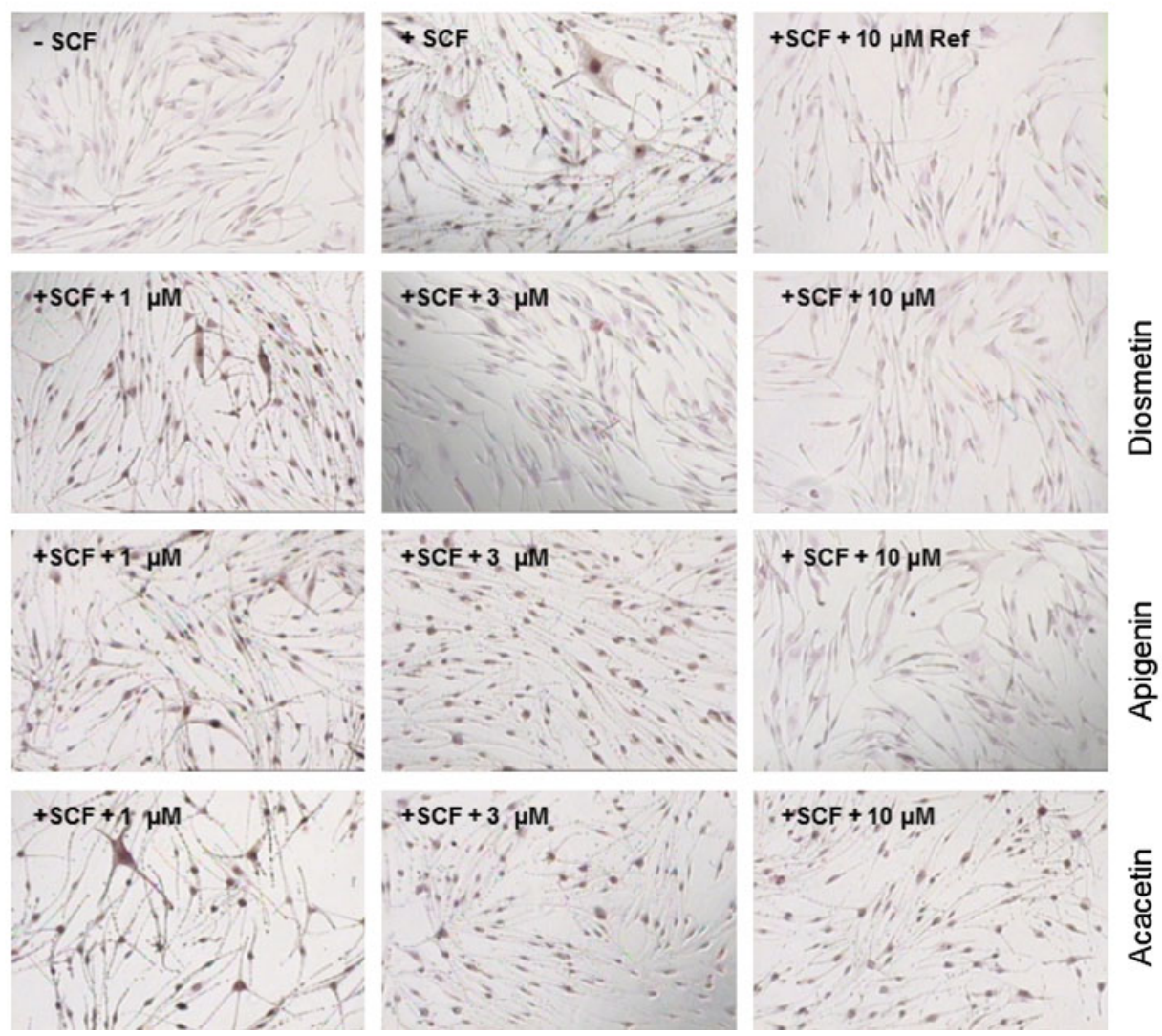

Fig. 5 Anti-pigmentation effect of flavonoids on human melanocytes. $\left[{ }^{14} \mathrm{C}\right]$-tyrosine incorporation was induced by $100 \mathrm{ng} / \mathrm{mL} \mathrm{SCF}$ (a) or $30 \mathrm{~mJ}$ UVB (b) in human melanocytes. Cells were sequentially treated with $3 \mu \mathrm{M}$ of compounds and $0.03 \mu \mathrm{Ci}$ of $\left[{ }^{14} \mathrm{C}\right]$-tyrosine for

flavonoids (Fig. 5b). Diosmetin, apigenin and acacetin showed considerable suppression of the increased tyrosineincorporation by UVB irradiation. Both the tyrosine and DOPA incorporation assays demonstrated consistent results for the inhibitory potency of diosmetin, reflecting the reduction of melanin content by diosmetin at $\geq 3 \mu \mathrm{M}$ (Fig. 5c). The same pattern was observed in mouse melanocytes (data not shown).
$48 \mathrm{~h}$, and then processed for analysis. C. The SCF-induced pigmentation was blocked by flavonoids in human melanocytes. Cells were pre-treated with compounds, then incubated with $100 \mathrm{ng} / \mathrm{mL}$ of SCF for $48 \mathrm{~h}$. The photographs were taken under a microscope $(\times 100)$

Diosmetin showed effective anti-pigmentation activity in a human melanoderm model

Diosmetin suppressed basal melanin synthesis and SCFinduced pigmentation in the MelanoDerm ${ }^{\mathrm{TM}}$ system, a highly differentiated model of human epidermis that consisted of multilayered epidermal keratinocytes and melanocytes (Fig. 6). Diosmetin considerably lightened the tone 


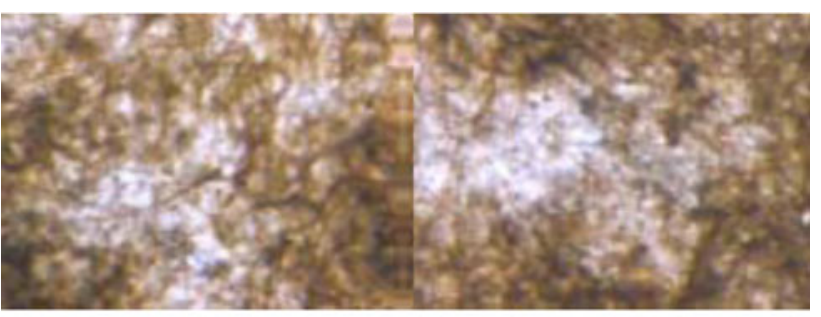

Control (PBS)

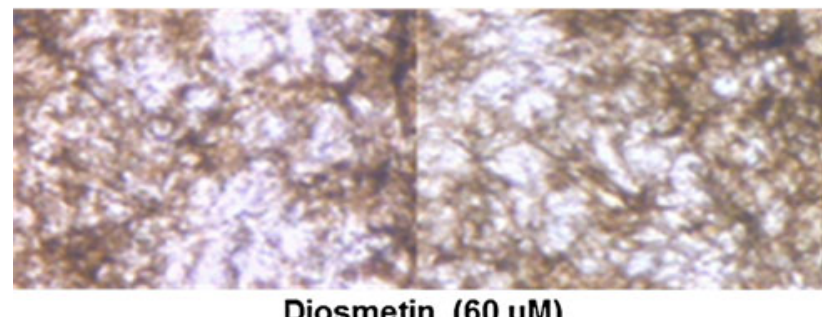

Diosmetin $(60 \mu \mathrm{M})$

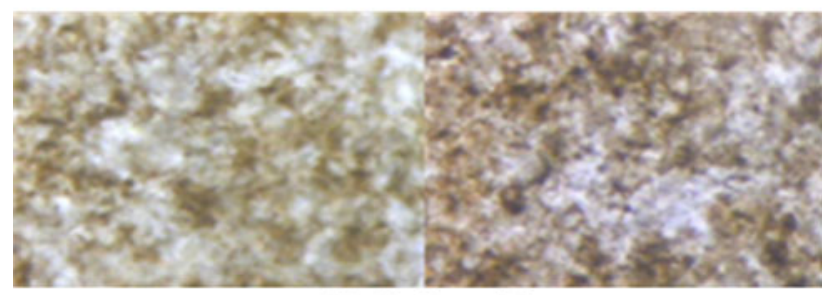

$1 \%$ Kojic acid

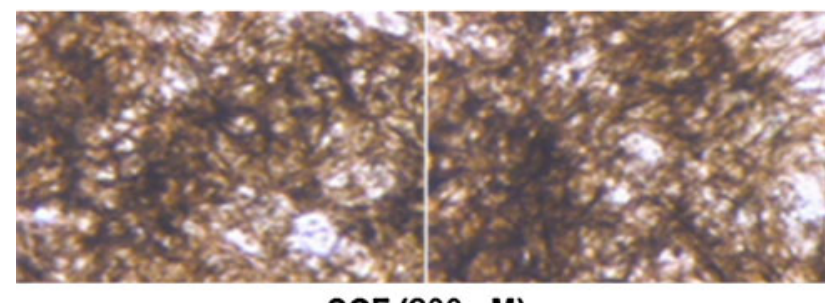

SCF (200 nM)

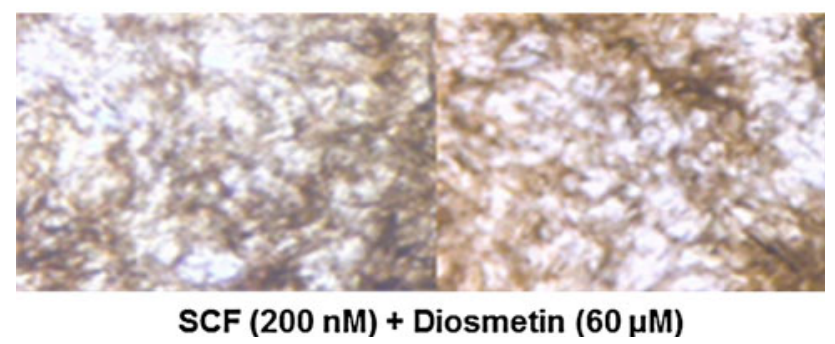

Fig. 6 MelanoDerm assay. After SCF $(200 \mathrm{ng} / \mathrm{mL})$ treatment for three days, diosmetin $(60 \mu \mathrm{M})$ or kojic acid (1\%) was applied, and cells were incubated for two more weeks. Each melanoderm was fixed with $10 \%$ formalin and photos were taken from the top-view with a phase contrast microscope at $\times 100$ magnification

of the dermis compared to untreated controls. Kojic acid (1\%), one of the most frequently used depigmentation agents, was applied as a positive control. The concentration of diosmetin and Kojic acid was determined from a preliminary experiment. Diosmetin $60 \mu \mathrm{M}$ (equal to $0.018 \%$ ) showed effective prevention of SCF-induced melanogenesis in a MelanoDerm experiment performed for 2-weeks.

\section{Discussion}

SCF is an important factor that stimulates the proliferation and melanogenesis of melanocytes and mediates the pigmentation response to UV irradiation (Imokawa 2004; Kawaguchi et al. 2001). Blocking SCF/c-Kit signaling can reduce differentiation of melanoblasts and proliferation of melanocytes (Nishimura et al. 2002). Furthermore, administration of small molecules that specifically inhibited c-Kit showed inhibition of melanogenesis in mice, brown guinea pigs, and human beings (Brazzelli et al. 2007; Na et al. 2007).

To date, tyrosinase has been a major target of whitening agents like hydroquinone and arbutin, but their whitening effects were insufficient and transient. Therefore, in this study, we attempted to discover more effective depigmentation agents by screening plant extracts for novel c-Kit inhibitors. The rational design of synthetic chemicals sometimes yields the most potent and selective inhibitors for therapeutic targets. However, plants and herbs provide invaluable sources in the development of novel medicines and novel scaffolds for therapeutic agents. Many compounds derived from herbs and plants are highly bioactive and merit development as drugs (Pieroni et al. 2004). However, plant extracts typically contain high amounts of fluorescent phytochemicals. Therefore, homogeneous highthroughput screening methods like fluorescent resonance energy transfer (FRET) are improper due to the high background noise. In order to remove the difficulty of internal fluorescence, we adopted a TRF assay that used antibodies labeled with europium; Low backgrounds could be achieved because of the time-difference between excitation and emission fluorescence.

In this study, we found that the accelerated melanin synthesis and proliferation induced by SCF were reduced with the addition of diosmetin. This SCF-inhibitory effect was equivalent to that of the reference compound (521232). The results from the melanoderm tissue model implied that $60 \mu \mathrm{M}$ diosmetin $(0.0018 \%)$ had higher efficacy than the reference inhibitor, kojic acid (1\%), without any toxicity. Furthermore, we assessed the allergenic potential of diosmetin with a local lymph node assay in BALB/C mice. The results showed that diosmetin did not induce an allergic response; Stimulus index (S.I.) were between 0.8 and 1.1 based on the isolated lymph cells from lymph node after 3-day treatment of 10, 20 and $30 \%$ diosmetin $(25 \mu \mathrm{L})$ on mice ears. In fact, diosmetin is already in use on the market as an anti-oxidative skin stress agent (Kaden Biochemicals GMBH, Germany); thus, its safety in one aspect has been previously approved.

In summary, diosmetin, isolated from a $C$. morifolium extract, showed dose-dependent inhibition of SCF-/UVBinduced pigmentation and c-Kit phosphorylation. In 
addition, diosmetin effectively blocked increases in proliferation and melanin synthesis induced by SCF in mouse and human cells. Investigations with mouse NCCmelan5 cells, human primary melanocytes, and MelanoDerm tissue showed diosmetin produced consistent anti-pigmentation effects. Therefore, as c-Kit inhibitors diosmetin and C. morifolium extracts could be potential candidates of effective whitening agents.

Acknowledgments This work was supported by a grant from Korea Research council for Industrial science and Technology (KK-1303D0) and the Global Frontier Project Grant (NRF-MIAXA002-20100029776) of National Research Foundation funded by the Ministry of Education, Science and Technology of Korea. The NCCmelan5 cells were a generous gift from Dr. Mizoguchi and Dr. Soma (St. Marianna University School of Medicine, Kawasaki, Japan).

Open Access This article is distributed under the terms of the Creative Commons Attribution License which permits any use, distribution, and reproduction in any medium, provided the original author(s) and the source are credited.

\section{References}

Agullo, G., L. Gamet-Payrastre, S. Manenti, C. Viala, C. Remesy, H. Chap, and B. Payrastre. 1997. Relationship between flavonoid structure and inhibition of phosphatidylinositol 3-kinase: A comparison with tyrosine kinase and protein kinase $\mathrm{C}$ inhibition. Biochemical Pharmacology 53: 1649-1657.

Alexeev, V., and K. Yoon. 2006. Distinctive role of the c-Kit receptor tyrosine kinase signaling in mammalian melanocytes. Journal of Investigative Dermatology 126: 1102-1110.

An, S.M., H.J. Kim, J.E. Kim, and Y.C. Boo. 2008. Flavonoids, taxifolin and luteolin attenuate cellular melanogenesis despite increasing tyrosinase protein levels. Phytotherapy Research 22: $1200-1207$.

Attoub, S., C. Rivat, S. Rodrigues, S. Van Bocxlaer, M. Bedin, E. Bruyneel, C. Louvet, M. Kornprobst, T. Andre, M. Mareel, J. Mester, and C. Gespach. 2002. The c-kit tyrosine kinase inhibitor STI571 for colorectal cancer therapy. Cancer Research 62: 4879-4883.

Brazzelli, V., F. Prestinari, T. Barbagallo, C. Rona, E. Orlandi, F. Passamonti, F. Locatelli, M. Zecca, S. Villani, and G. Borroni. 2007. A long-term time course of colorimetric assessment of the effects of imatinib mesylate on skin pigmentation: a study of five patients. Journal of the European Academy of Dermatology 21: 384-387.

Briganti, S., E. Camera, and M. Picardo. 2003. Chemical and instrumental approaches to treat hyperpigmentation. Pigment Cell Research 16: 101-110.

Cai, J.N., P. Basnet, Z.T. Wang, K. Komatsu, L.S. Xu, and T. Tani. 2000. Coumarins from the fruits of Cnidium monnieri. Journal of Natural Products 63: 485-488.

Christophoridou, S., P. Dais, L.H. Tseng, and M. Spraul. 2005. Separation and identification of phenolic compounds in olive oil by coupling high-performance liquid chromatography with postcolumn solid-phase extraction to nuclear magnetic resonance spectroscopy (LC-SPE-NMR). Journal of Agriculture and Food Chemistry 53: 4667-4679.

Hachiya, A., A. Kobayashi, A. Ohuchi, Y. Takema, and G. Imokawa. 2001. The paracrine role of stem cell factor/c-kit signaling in the activation of human melanocytes in ultraviolet-B-induced pigmentation. Journal of Investigative Dermatology 116: 578-586.

Halaban, R. 2000. The regulation of normal melanocyte proliferation. Pigment Cell Research 13: 4-14.

Hemesath, T.J., E.R. Price, C. Takemoto, T. Badalian, and D.E. Fisher. 1998. MAP kinase links the transcription factor Microphthalmia to c-Kit signalling in melanocytes. Nature 391: 298-301.

Hirobe, T. 2005. Role of keratinocyte-derived factors involved in regulating the proliferation and differentiation of mammalian epidermal melanocytes. Pigment Cell Research 18: 2-12.

Hirota, S., K. Isozaki, Y. Moriyama, K. Hashimoto, T. Nishida, S. Ishiguro, K. Kawano, M. Hanada, A. Kurata, M. Takeda, G. Muhammad Tunio, Y. Matsuzawa, Y. Kanakura, Y. Shinomura, and Y. Kitamura. 1998. Gain-of-function mutations of c-kit in human gastrointestinal stromal tumors. Science 279: 577-580.

Hosaka, E., Y. Soma, Y. Kawa, H. Kaminaga, K. Osumi, S. Ooka, H. Watabe, M. Ito, F. Murakami, and M. Mizoguchi. 2004. Effects of ultraviolet light on melanocyte differentiation: studies with mouse neural crest cells and neural crest-derived cell lines. Pigment Cell Research 17: 150-157.

Huang, Y.T., J.J. Hwang, P.P. Lee, F.C. Ke, J.H. Huang, C.J. Huang, C. Kandaswami, E. Middleton Jr, and M.T. Lee. 1999. Effects of luteolin and quercetin, inhibitors of tyrosine kinase, on cell growth and metastasis-associated properties in A431 cells overexpressing epidermal growth factor receptor. British Journal of Pharmacology 128: 999-1010.

Imokawa, G. 2004. Autocrine and paracrine regulation of melanocytes in human skin and in pigmentary disorders. Pigment Cell Research 17: 96-110.

Kandaswami, C., L.T. Lee, P.P. Lee, J.J. Hwang, F.C. Ke, Y.T. Huang, and M.T. Lee. 2005. The antitumor activities of flavonoids. In Vivo 19: 895-909.

Kato, M., K. Takeda, Y. Kawamoto, T. Tsuzuki, K. Hossain, A. Tamakoshi, T. Kunisada, Y. Kambayashi, K. Ogino, H. Suzuki, M. Takahashi, and I. Nakashima. 2004. c-Kit-targeting immunotherapy for hereditary melanoma in a mouse model. Cancer Research 64: 801-806.

Kawaguchi, Y., N. Mori, and A. Nakayama. 2001. Kit(+) melanocytes seem to contribute to melanocyte proliferation after UV exposure as precursor cells. Journal of Investigative Dermatology 116: 920-925.

Kraus, G.A., J. Wie, and A. Thite. 2008. Reactions of carbanions with 1,3-benzodioxin-4-ones: Facile routes to flavones, aurones, and acyl phloroglucinols. Synthesis 15: 2427-2431.

Lee, S.J., D. Jeong, W.K. Park, J.Y. Kong, G. Choi, H. Kim, S. Kang, and H. Cho. 2009. Screening of Kit inhibitors: suppression of Kit signaling and melanogenesis by emodin. Phytotherapy Research 24: 308-312.

Mol, C.D., D.R. Dougan, T.R. Schneider, R.J. Skene, M.L. Kraus, D.N. Scheibe, G.P. Snell, H. Zou, B.C. Sang, and K.P. Wilson. 2004. Structural basis for the autoinhibition and STI-571 inhibition of c-Kit tyrosine kinase. Journal of Biological Chemistry 279: 31655-31663.

Na, Y.J., H.S. Baek, S.M. Ahn, H.J. Shin, I.S. Chang, and J.S. Hwang. 2007. [4-t-Butylphenyl]- $N$-(4-imidazol-1-yl phenyl)sulfonamide (ISCK03) inhibits SCF/c-kit signaling in $501 \mathrm{mel}$ human melanoma cells and abolishes melanin production in mice and brownish guinea pigs. Biochemical Pharmacology 74: 780-786.

Nagata, H., S. Takekoshi, R. Takeyama, T. Homma, and R. Yoshiyuki Osamura. 2004. Quercetin enhances melanogenesis by increasing the activity and synthesis of tyrosinase in human melanoma cells and in normal human melanocytes. Pigment Cell Research 17: 66-73.

Nishimura, E.K., S.A. Jordan, H. Oshima, H. Yoshida, M. Osawa, M. Moriyama, I.J. Jackson, Y. Barrandon, Y. Miyachi, and S. 
Nishikawa. 2002. Dominant role of the niche in melanocyte stem-cell fate determination. Nature 416: 854-860.

Ohguchi, K., Y. Akao, and Y. Nozawa. 2006. Stimulation of melanogenesis by the citrus flavonoid naringenin in mouse B16 melanoma cells. Bioscience, Biotechnology, and Biochemistry 70: 1499-1501.

Ooka, S., Y. Kawa, M. Ito, Y. Soma, and M. Mizoguchi. 2001. Establishment and characterization of a mouse neural crest derived cell line (NCCmelan5). Pigment Cell Research 14: 268-274.

Pieroni, A., C.L. Quave, M.L. Villanelli, P. Mangino, G. Sabbatini, L. Santini, T. Boccetti, M. Profili, T. Ciccioli, L.G. Rampa, G. Antonini, C. Girolamini, M. Cecchi, and M. Tomasi. 2004. Ethnopharmacognostic survey on the natural ingredients used in folk cosmetics, cosmeceuticals and remedies for healing skin diseases in the inland Marches, Central-Eastern Italy. Journal of Ethnopharmacology 91: 331-344.

Roskoski Jr, R. 2005. Signaling by Kit protein-tyrosine kinase: The stem cell factor receptor. Biochemical and Biophysical Research Communications 337: 1-13.
Seijas, J.A., M.P. Vazquez-Tato, and R. Carballido-Reboredo. 2005. Solvent-free synthesis of functionalized flavones under microwave irradiation. Journal of Organic Chemistry 70: 2855-2858.

Sugumaran, M. 2002. Comparative biochemistry of eumelanogenesis and the protective roles of phenoloxidase and melanin in insects. Pigment Cell Research 15: 2-9.

Tachibana, M. 2000. MITF: A stream flowing for pigment cells. Pigment Cell Research 13: 230-240.

Tobiishi, M., A. Haratake, H. Kaminaga, M. Nakahara, A. Komiya, H. Koishikawa, H. Uchiwa, Y. Kawa, and M. Mizoguchi. 2005. Changes in responses of UVB irradiated skin of brownish guinea pigs with aging. Pigment Cell Research 18: 278-284.

Tsao, A.S., H. Kantarjian, J. Cortes, S. O'Brien, and M. Talpaz. 2003. Imatinib mesylate causes hypopigmentation in the skin. Cancer 98: 2483-2487.

Wehrle-Haller, B. 2003. The role of Kit-ligand in melanocyte development and epidermal homeostasis. Pigment Cell Research 16: 287-296. 